\title{
Bridging the gap: the challenges of employing entrepreneurial processes within university settings.
}

\author{
Dorothy Wardale $^{1}$ and Linley Lord \\ Curtin Graduate School of Business, Curtin University, Perth, Australia
}

\begin{abstract}
In Australia and elsewhere, universities face increasing pressure to improve research output and quality, particularly through partnerships with industry. This raises interesting challenges for academic staff with considerable industry experience that are 'new' to academe. Some of these challenges were faced by the authors who have been successful in generating research, consultancy and executive education funds since joining academe and been somewhat surprised at being described as successful researchers and entrepreneurs. Taking a reflexive look to identify and make explicit our practice through the lenses of social capital and the entrepreneurial process, we identified ten practices. However, we remain troubled by the dissonance between organisational rhetoric and its rewards for entrepreneurial activities. We offer some considerations for universities to help bridge this gap.
\end{abstract}

Keywords: entrepreneurship, social capital, relationship building, structural social capital universities, organisational dissonance.

\section{Introduction}

This paper arose from discussions regarding transitioning from industry to academic careers. We work at a business school within a university. Business schools are less likely to attract large grants, instead often focusing on funding from industry for applied research (Triechmann et al., 2000; Zimmerman, 2001). In the report 'Impact of Research A Guide for Business Schools - Insights from the AACSB International Impact of Research Exploratory Study' the Association to Advance Collegiate Schools of Business (AACSB) (2012) notes the importance of research in business schools and the opportunity that exists for increasing visibility and value through connecting with industry.

We were intrigued to find ourselves considered successful by colleagues, within our school and at academic conferences. However, we were unsure what they meant by

${ }^{1}$ Corresponding author: d.wardale@iinet.net.au 
'successful'. They cited our industry connections and ability to source reasonable levels of funding (e.g. from \$AUD 10,000 to \$AUD 1,000,000) for contract research and executive education. However, we were aware of the reward systems that focussed on more traditional academic outputs. We had extensive networks within academe and industry; we had spoken at various industry forums and national lecture series, and were able to introduce colleagues to industry partners.

These perceived strengths, whilst flattering, lead to a level of curiousness about colleagues' perceptions of what they saw as distinctive. From our perspective we were trying to build new careers as academics and this was not without its challenges, as our efforts were not wholly recognised by the established organisational and external reward systems. For example, external measures such as 'Excellence in Research Australia' favour traditional, long-term academic careers. Similarly, our lack of traditional academic track record made us appear a poor choice for established research teams.

The requests from colleagues to 'share' our story in relation to industry funding success led us to critically reflect on our practice (Voronov et al., 2009). We were interested in organisational discourses relating to research productivity (White, Carvalho, \& Riordan, 2011) and its rewards. Linked to this were discussions on the inappropriateness of uniform research expectations across all universities (for example, Hewitt-Dundas, 2012).

Our initial reflection led us to identify ten practices that guide the way we attract funding for applied research and executive education. We believe these might be useful for other academics (Authors 2012, 2013). This is contextualised to business schools and while this may be applicable to other colleagues we are not making this claim. Further reflection had led us to think more about gaps we perceive between the rhetoric of entrepreneurialism and industry connection and the reality of organisational rewards for traditional academic outputs.

This paper links our ten practices on university collaborations with industry in its broadest sense. We discuss the tension felt being perceived as successful academics by peers, at one level, but at another, not necessarily recognised or rewarded at the organisational level.

At times, we found the level of university bureaucracy and risk aversion resulted in a lack of responsiveness to industry demands. We highlight tensions between various organisational activities and their rewards. Against this backdrop we provide an overview of relevant literature on increasing managerialism and the call for greater entrepreneurialism in universities. This is followed by an explanation of the theoretical insights we drew upon to reflect on our practice and to provide a framework for questioning organisational norms. We conclude with a discussion on implications for those making the transition from industry to academe. 


\section{Higher education in Australia}

Academics are not immune from the constraints of bureaucracy (Musselin, 2013). Mintzberg (1979) argues that academia necessitates the blending of professional autonomy within formal bureaucratic controls creating a 'professional bureaucracy'.

There is little dispute that the balance between professional autonomy and bureaucracy has skewed recently, as universities shift from collegial to managerial institutions (Anderson, 2006; Dearlove, 2002; Deem, 1998; Hil, 2012; Musselin 2013). This has seen the imposition of management techniques derived from large private businesses onto public sector organisations (Frey et al., 2013; Deem; 2001,Hood, 1995; Deem, 1998). Universities have seen the introduction of activities including strategic planning, performance management, budgeting and quality assurance.

Such changes have been seen as particularly urgent in Australian universities, as they address the issue of 'infinite mission, finite means' (Sharrock, 2012, p. 323). Public funding declined further following the introduction of a two-percent 'efficiency dividend' by the Federal Government (ABC News 2013). Adding to this pressure has been increases in student numbers without corresponding increases in staff (Coates et al., 2010). Universities are exposed to market forces, driven by an increasingly globalised and commercialised education system (Dearlove, 2002; Sharrock, 2012; Sharrock, 2007).

A sympathetic view of university managerialism is that institutional leadership is required to adapt to new tasks and problems facing universities (Ramsden, 1998; Sharrock, 2007; Sharrock, 2012). However, the suitability of corporate processes in a university setting has been widely questioned (Harman \& Treadgold, 2007; Kenny, 2009). Also argued is the increasingly commercial focus of universities may undermine academic values, research independence, and academic autonomy (White, Carvalho, \& Riordan, 2011; Musselin, 2013). Managerialism appears to have a negative effect on staff morale. Studies show the intensification of academic workloads, increasing administrative demands and reduced time for research may impact on promotional prospects and self-esteem of researchers (Anderson, 2006; Szekeres, 2007; Pick, Teo, \& Yeung, 2012). Fredman and Doughney (2012, p. 42) argue that Australian academics have 'troubling levels of dissatisfaction and discontent' stemming from unhappiness with university management.

Proposed further deregulation of higher education in Australia, places additional pressure on academic staff to achieve more against diminishing government funding (Bexley, 2014). The pressure to teach at a high level, research, secure funding and engage with industry appears unrelenting.

\section{Theoretical Frameworks}

We draw on three theoretical frameworks that inform our reflection and discussion. The first, 'crowding out', critically assesses how activities and behaviours are monitored, measured, and motivated. The second, 'academic entrepreneurship' explores expectations relating to teaching, research and, more recently, to attracting significant 
funding. The third concept, 'social capital', refers to individuals' ability to build strong and productive networks, recognised as 'an important source of competitive advantage for all organisations' (Lee, 2008, p. 258). These are explained in more detail below.

\section{Crowding-out}

Crowding out is based on the proposition that two key kinds of motivation are utilised when performing a task: extrinsic motivation, where rewards are externally imposed, and intrinsic motivation, where rewards are internally driven. Evidence suggests that extrinsic motivation may have a 'crowding-out' effect on intrinsic motivation (Frey, 1997 in Osterloh et al., 2001). Firstly, where extrinsic motivations are seen as being 'controlling' (that is, limiting self-determination), the intrinsic motivations decrease (Frey, 1997; Osterloh et al., 2001). Secondly, without acknowledgement of the actor's intrinsic motivation, outside intervention can decrease it (Frey, 1997). Careful balancing is required to ensure that 'crowding-out' does not occur or is limited (Osterloh et al., 2001).

A meta-analysis of 'pay for performance' schemes in the public service, (Weibel et al., 2009) found increases in the performance of 'non-interesting' tasks and a decline in performance of 'interesting' tasks (involving challenges, enjoyment and a sense of purpose). Weibel et al. conclude that the decline in performance of interesting tasks demonstrates a 'crowding-out' effect that may present a hidden cost. This resonates with criticisms of managerialism in universities. The autonomy traditionally exercised by academics in complex roles makes monitoring and measurement difficult. However, if roles are changed to assist monitoring and measurement, they become less interesting and motivation is reduced. Paradoxically, this may have implications for productivity and innovation (Blackmore \& Kandiko, 2012).

\section{Academic entrepreneurship}

Definitions of entrepreneurship vary (Shane 2003). Essentially an entrepreneurial act is one that involves the innovative use of resources to create new goods, services, methods or processes (Abreu and Grinevich, 2013). The three common stages within the entrepreneurial process are shown in Figure 1 (Goxe and Viala, 2010; Ireland, Kuratko \& Morris, 2006; Shane and Venkataraman 1996; Wilken, 1979).

Figure 1: Stages of Entrepreneurial Process

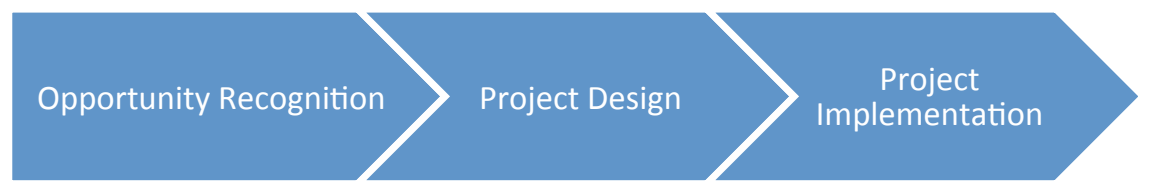

This process creates tension in the context of the managerial university. Bridgman (2007) argues that academic freedom has been replaced with the freedom to be 'entrepreneurial' in seeking new sources of revenue. In this context, the 
'entrepreneurial academic' has emerged as a new role model in university settings (Lambert, 2003 as cited in Bridgman, 2007).

Entrepreneurial academics address the 'third mission' of academic engagement: the transfer of knowledge to industry. Broadly, this involves two key areas of entrepreneurial activity (Wright et al., 2012; Perkmann et al., 2013). The first is 'commercialisation' which is beyond the scope of this paper. The second is 'academic engagement' (Abreu and Grinevich, 2013) involving some form of quid-pro-quo exchange (financial or otherwise) with goals beyond research and publication (Perkmann et al., 2013). This sits clearly within the expertise of business schools. Academic engagement, in part, is promoted through building partnerships, and collaboration with industry (Carr, 2011), through activities including contract research, consulting, advisory board membership, joint research and development, and executive education (Perkmann et al., 2013; Abreu and Grinevich, 2013). Academic seniority (Perkmann et al., 2013) and previous business experience (Abreu and Grinevich, 2013) have a positive effect on academic engagement with industry and can act as a precursor to academic entrepreneurship by identifying opportunities and risk in terms of cost and time (Abreu and Grinevich, 2013).

\section{Social capital}

D'Este and Patel (2007) assert that personal characteristics of individual academics have a greater impact on frequency of interactions with industry than the characteristics of their university. . These characteristics are largely associated with social capital's three core dimensions: structural, cognitive and relational (Goxe \& Viala, 2010; Lawson, Tyler, and Cousins, 2006; Lee 2008; Luthans \& Leung, 2010; Moran, 2005; Nahapiet \& Ghosal, 1998; Tsai and Ghosal, 1998; Zahra, 2010). In the context of this paper social capital is linked with facilitating academic engagement and industry networks (Perkmann et al., 2013).

Structural social capital refers to the position of the actor within a social network and the frequency of contact with that network. This gives rise to social interactions, and may expose the actor to benefits (e.g. using contacts to obtain information) or detriments (De Carolis \& Saparito, 2006; Nahapiet \& Ghoshal, 1998; Tsai and Ghoshal, 1998; Liao and Welsch, 2003).

Relational social capital refers to the content of the actor's personal relationships (Nahapiet \& Ghoshal, 1998; Tsai \& Ghoshal, 1998; Liao \& Welsch, 2003). Trust and trustworthiness, obligations, openness, expectations, norms and identities are assets, which can be 'created and leveraged' through personal relationships (Nahapiet \& Ghoshal, 1998. p. 244).

Cognitive social capital includes 'those resources providing shared representations, interpretations, and systems of meaning among parties' (Nahapiet and Ghoshal 1998, p. 244). For example, a social network may have a shared vision or collective goals that affect the conduct of those within the network (Tsai \& Ghoshal, 1998). According to De Carolis and Saparito (2006, p. 45) 'shared systems of meaning 
and language facilitate the exchange of information, learning and knowledge creation that allows individuals to share each other's thinking processes'.

\section{Approach}

Academics within business schools are generally expected to undertake 'academic engagement'. We agree with Bercovitz and Feldman (2008) that the skills required for industry involvement are different to the skills required for traditional measures of academic success. A challenge for academic staff in business schools is to develop and maintain effective relationships with industry that meet both the university's needs for traditional research outputs and industry's needs for innovation and rapid problem solving. However, 'for most universities, even those with cuttingedge research, partnering with industry does not come naturally' (Edmondson et al., 2012).

In this section we reflect on our experience of building social capital and connecting with industry. We describe the ten practices we identified as important for successful, individual academic entrepreneurship. We consider the implications of these practices for academics working within business schools. The approach we have taken can help build bridges between industry and the university particularly at the individual level. Our challenge is to exercise this knowledge and experience within organisational frameworks that purport to be entrepreneurial, but which appear to do little to encourage this at the individual level.

Schön's (1983) 'Reflection in Action' provided the framework for reflecting on what we were doing while we were doing it. We had largely assumed that clients engaged us for what we knew. In part, this was true. However, as Washington (2008) points out, it's whom you know (social capital) as well as what you know that has the greatest impact on securing work.

Our reflections led us to realise we had been following Washington's advice and actively developing our social capital (Nahapiet \& Ghoshal, 1998) in both quantity and quality of our relationships with our industry counterparts (see also Bilimoria, Goodwin $\&$ Zelechowski, 2007). Through our interactions we were 'able to access and leverage resources embedded in relationships' (Luthans \& Leung, 2010, p. 686).

\section{The ten practices}

We identified ten practices we believe relevant to acquiring external industry based funding. They assume a close relationship with industry and juggling of sometimes complementary and sometimes competing demands. We used the mnemonic STRESS FREE (derived by using the first letter of each of the practices) to describe them. These are shown in Table 1: 
Table 1: Ten STRESS FREE practices.

\begin{tabular}{|c|c|}
\hline Practices & Description \\
\hline Seize opportunities & $\begin{array}{l}\text { Attentive to recognising and acting on potential opportunities } \\
\text { including: } \\
\text { - casual conversations relating to organisational challenges } \\
\text { or issues } \\
\text { - networking functions } \\
\text { - conferences and presentations } \\
\text { - formal and informal meetings }\end{array}$ \\
\hline Tactical & $\begin{array}{l}\text { Knowing when to say yes and more importantly when to say no } \\
\text { to opportunities including when: } \\
\text { - the opportunity is unsuitable (time, skills, insufficient } \\
\text { funding) } \\
\text { - time could be used more effectively building longer-term } \\
\text { relationships }\end{array}$ \\
\hline $\begin{array}{l}\text { Relationship } \\
\text { Building }\end{array}$ & $\begin{array}{l}\text { Building genuine relationships. Our approach includes: } \\
\text { - genuine interest in the organisation } \\
\text { - } \text { questioning and suggesting options } \\
\text { - } \text { staying in touch formally and informally } \\
\text { - } \text { sending articles that will be of interest }\end{array}$ \\
\hline Energy & $\begin{array}{l}\text { Energy and tenacity are required. We acknowledge that: } \\
\text { - large research applications or tenders take time } \\
\text { - } \text { sustaining projects to successful outcomes requires } \\
\text { considerable personal investment } \\
\text { - industry timelines can be considerably shorter than } \\
\text { university timeframes }\end{array}$ \\
\hline Solution-focused & $\begin{array}{l}\text { Being solution-focused rather than theory-focused. As a result } \\
\text { we: } \\
\text { - present outcomes in formats that are readily accessible to } \\
\text { industry partners }\end{array}$ \\
\hline Strengths & $\begin{array}{l}\text { Awareness of our strengths and weaknesses, seeking } \\
\text { opportunities to: } \\
\text { - build or work in strong, diverse teams that complement } \\
\text { our strengths and enable us to learn and develop from } \\
\text { others. }\end{array}$ \\
\hline Feedback & $\begin{array}{l}\text { Providing regular feedback utilising the 'no-surprises' rule. We: } \\
\text { - build in regular informal feedback as well as formal } \\
\text { contractual feedback requirements } \\
\text { - discuss the results before they are formally presented and } \\
\text { situate them in the broader research context leading to } \\
\text { meaningful discussions regarding possible } \\
\text { recommendations }\end{array}$ \\
\hline
\end{tabular}




\begin{tabular}{|c|c|}
\hline & $\begin{array}{l}\text { - have regular updates regarding timeframes, problems, } \\
\text { budget, highlights, early findings and warnings of } \\
\text { potential bad news. }\end{array}$ \\
\hline Reciprocity & $\begin{array}{l}\text { Engaging in reciprocal behaviour. We: } \\
\text { - } \text { share our ideas and the tools we have developed } \\
\text { - focus on further opportunities that might arise }\end{array}$ \\
\hline $\begin{array}{l}\text { Engage in the } \\
\text { Process }\end{array}$ & $\begin{array}{l}\text { Engaging in the process means we: } \\
\text { - make time to establish habits and routines that allow us to } \\
\text { build and maintain relational social capital } \\
\text { - commit time to networking, enquiring and writing } \\
\text { funding applications }\end{array}$ \\
\hline Exchange Rate & $\begin{array}{l}\text { Understanding the value of our work, including its opportunity } \\
\text { cost. This means we are aware of: } \\
\text { - appropriate charge-out rates for our expertise } \\
\text { - the cost of saying yes } \\
\text { - the cost of saying no }\end{array}$ \\
\hline
\end{tabular}

Through a process of iteration, we shared these practices with colleagues within our School and at conferences and they seemed to resonate. Feedback indicated that the framework was helpful for thinking about what might be required to engage in more effective and productive relationships with industry. They also noted that it helped highlight the time and energy required to build and maintain industry connections and how this potentially conflicts with other organisational demands for research output and teaching excellence.

Their feedback led to further reflection on the links between the development of social capital and the practices we had identified. We acknowledge and have felt the tension that exists between what is being asked and what is rewarded. We have felt 'crowded out' (Osterloh et al., 2001) because of the emphasis in the current reward structures for more traditionally based research outcomes. This can be at odds to industry's needs for shorter term, solution-focused results and contractual arrangements may preclude opportunities for research publication.

\section{Analysis}

Our personal motivations for applied research mirrored D'Este and Perkmann's (2010) finding that academics engage with industry to develop their research careers rather than any monetary rewards associated with commercialisation. As such, academics need strategies for engagement with industry that allow them to further build research reputation. We knew that social capital needed to be interrogated further and that academics need to be entrepreneurial,.. We were conscious that the some measures increasingly imposed on academics were crowding out their intrinsic motivation. Thus, 
developing and implementing the ten practices may help both individuals and their universities.

Mapping the STRESS FREE practices against social capital theory and the stages of the entrepreneurship process helped us identify common elements that offer an explanation as to why our approach has been successful. Table 2 summarises this comparison. The primary emphasis of the practices has been assumed for the sake of clarity and the various cells in the table are numbered for ease of reference in the discussion below.

Table 2: Social capital and entrepreneurial aspects of the STRESS FREE practices.

\begin{tabular}{|c|c|c|c|c|}
\hline & \multicolumn{3}{|c|}{ Stage of the Entrepreneurial Process } \\
\hline & & Opportunity recognition & Project design & Project implementation \\
\hline \multirow{3}{*}{ 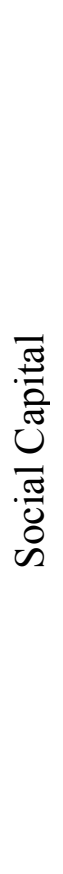 } & $\begin{array}{l}\text { Structural } \\
\text { SC }\end{array}$ & $\begin{array}{l}\text { Seize opportunities } \\
\text { Relationship building } \\
\text { Energy } \\
\text { Tactical } \\
\text { Engage in the Process }\end{array}$ & $\begin{array}{l} \\
\text { Feedback } \\
\text { Energy } \\
\text { Tactical } \\
\text { Engage in the Process }\end{array}$ & $\begin{array}{l}\text { Tactical } \\
\text { Energy } \\
\text { Feedback } \\
\text { Engage in the Process }\end{array}$ \\
\hline & $\begin{array}{l}\text { Cognitive } \\
\text { SC }\end{array}$ & $\begin{array}{c}4 . \\
\text { Solution-focused }\end{array}$ & \begin{tabular}{l}
\multicolumn{1}{c}{5.} \\
Solution-focused \\
Exchange Rate
\end{tabular} & $\begin{array}{c}6 . \\
\text { Solution-focused }\end{array}$ \\
\hline & $\begin{array}{l}\text { Relational } \\
\text { SC }\end{array}$ & $\begin{array}{l}\text { Seize opportunities } \\
\text { Reciprocity } \\
\text { Relationship building } \\
\text { Engage in the process }\end{array}$ & $\begin{array}{l}\quad 8 . \\
\text { Seize opportunities } \\
\text { Relationship building } \\
\text { Strengths } \\
\text { Feedback }\end{array}$ & $\begin{array}{l}\qquad 9 . \\
\text { Reciprocity } \\
\text { Relationship building }\end{array}$ \\
\hline
\end{tabular}

'Seize opportunities' sits primarily within cells 1,7 and 9 and relates to opportunities for contact and relationships that are supportive enough to win and genuinely grow work. We have found that the project scope often grows if the client, academic and business school see mutual benefit in using a 'best for project' approach. This can lead to a range of further opportunities. When academics and business schools are attentive to industry's needs they can often circumvent protracted and costly tendering systems to deliver focused research or consultancy that addresses the needs of the industry client. Similarly, creativity and innovation are likely to flourish in a context of relational embeddedness.

'Tactical' is placed in Structural cells 1, 2 and 3. It is important to know when to invest and when to withdraw or minimise social connections. Some projects, like some colleagues and students, can be very time consuming. This approach recognises it is 
vital to appreciate what constitutes a wise investment. How this links to rewards systems can mean that such efforts are crowded out by extrinsic factors that are more easily measured by the organisation.

'Relationship building' is primarily placed in the Relational cells 1, 7, 8 and 9. We have found that creating frequent and varied connections (Structural category 1) is important. However, it is the quality of the relationship and the mutual trust that is built that weighs more on our ability to secure funding. This can be achieved at the individual academic level or for the school. The latter has longer-lasting advantages as staff move away but the relationship with the 'local and trusted' business school remains.

Having 'Energy' fits across many of the cells. However, we have placed it primarily in Structural cells 1, 2 and 3. Largely this refers to an academic's energy to be conscious of opportunities, design projects and stay connected throughout the implementation phase. However, the business school can support this effort by not 'crowding out' the individual's motivation and by shielding them from, at least, some of the university's bureaucracy.

Being 'solution-focused' is primarily related to the Cognitive cells 4, 5 and 6. It is about seeing the project (research or otherwise) as a problem to be solved with and for the organisation or client. As stated previously, although industry tends to want answers, not theories the development and/or testing of theory and applied research are not mutually exclusive. Our point is that the expectations of both parties need to be clearly articulated and agreed at the beginning of projects. It is also important that reports are written in terms that are accessible to industry. This can mean two papers: the academic paper and the business report. Academic's involvement with industry helps maintain contemporary business language, skills and case studies to support industry as well as current knowledge to share with their students.

'Strengths' fits primarily in cell 8. It is important to know our own strengths and weaknesses and to have the depth of collegial networks to draw on when developing a successful collaboration. University recognition of the importance of collaboration needs to be reflected in reward systems to encourage team-based industry research.

'Feedback' sits clearly within the Structural cells 2 and 3 as well as the Relational cell 8 . We believe that it is both the regularity and honesty of feedback that leads to successful project completion. Creating feedback loops, inclusive of doubleloop learning (Argyris, 1976), and acting genuinely on this feedback is likely to produce effective outcomes in terms of the project and the long-term client-consulting-academic relationship.

The principle of 'Reciprocity' is embedded in the Relational cells 7 and 9. A willingness to share information, the latest research and accept speaker invitations is likely to develop the relationship and the opportunity for further, deeper and more innovative work. We have found that business schools that foster frequent and close relationships with industry through mutual guest speaker programs, advisory board membership and informal advice are likely win and build work more so than those that do not. 
'Engage in the Process' is in Structural cells 1, 2 and 3. Making enough time to network and discover the opportunities that exist is an important first step. However, if the design and follow-through is not conducted effectively then the opportunity for repeat business will diminish. Engaging in the process also means that we are fully attentive and responsive to the issues; it is not a one-size-fits-all approach. This aligns with Relational cells 7 and 8. Crowding out can deter academics from this process through the increasing demands on administration and some business schools viewing networking as time wasting. Significant personal expenses when networking for business purposes can be incurred whereas similar roles in private enterprise often have appropriate resources for such activities.

Finally, 'Exchange Rate' falls into the Cognitive cell 5, as it relates to Project Design. Knowing what fees will be acceptable to industry is part of having a 'shared code' with an industry partner. If too little is charged, the industry-partner is likely to think the work will be sub-standard; or if too high a fee is quoted then the potential partner may walk away from the project. Establishing a competitive fee and value proposition is vital for an effective exchange.

We contend that all dimensions of social capital, particularly structural and relational, are needed for academics to incorporate an entrepreneurial approach that facilitates effective relationships with industry. We have provided examples of how crowding out can exacerbate rather than bridge the gap towards academic entrepreneurialism. The examination of our observations through these lenses has highlighted our particular focus on creating time for structural social capital and building relational social capital. These align with Blatt's (2009) view that to be a successful entrepreneur requires more than opportunism and self-interest.

\section{Discussion}

Much of the research on public and industry connections has been undertaken in the context of general public service entities, rather than universities. To address this, our paper is interested in the challenges an entrepreneurial academic faces while operating within the confines of a 'professional bureaucracy' such a university.

To explore this we began our reflection in action to gain insight into what some were seeing as successful academic endeavours. We identified ten practices that ane level might be considered tacit knowledge based on industry experience prior to academe. Further reflection on these in the context of entrepreneurial approaches within the managerialist frameworks has provided insights into enabling and hindering processes and behaviours.

We can see from our analysis that most of the STRESS FREE practices sit within the Structural and Relational dimensions of Social Capital. We assert, in line with Adler and Kwon (2002), that is it important to create opportunities to meet and to maintain a frequency of contact with potential clients. The focus is to develop a trusting and trustworthy relationship. Cognitive social capital is essential to establishing a 
shared language and value set with industry partners and critical to building an entrepreneurial academic approach.

Christopher (2012, p. 562) points out that underlying the development of managerial practices 'is the notion that corporate managerialism emphasises minimizing cost and maximizing revenue'; that is, managerialism is seeking to promote a type of 'academic capitalism' (Slaughter \& Leslie, 1997, as cited in Deem, 2001, p. 8). This has led to a change in academic priorities; resulting in a more entrepreneurial approach focused on personal career advancement predominately based on strong research records (Kenny, 2009), which includes a growing emphasis on attracting external research money (Saunders, 2006). This increased emphasis on seeking external research funding particularly from industry should be complementary to the neoliberal underpinnings of managerialism; the promotion of efficiency through market-style reform of the public sector.

However, this has not been the experience of the authors. We found many policies and procedures have had the effect of hindering, rather than enabling, an entrepreneurial approach to attracting funding from industry. Superficially the goals of academic capitalism and managerialism appear to largely overlap (Deem, 2001). In practice, managerialist approaches appear to be counterproductive for producing an environment conducive to academic entrepreneurship. They can crowd out the natural enthusiasm of academics to invest their own time and resources and replace them with demands for KPIs, ${ }^{2}$ research productivity, teaching quality assessments, accounting for cost centres and reporting for universities' rankings and accreditations.

Research on the effect of the organisational context on academic enterprise (see Perkmann et al., 2013 for a detailed review) has shown that organisational factors may moderate individual entrepreneurial characteristics. There is, however, a lack of research on the possible effects of organisational constraints on entrepreneurial activity (Diefenbach, 2011). More specifically, research is needed into the different types of constraints and their specific influences on entrepreneurship (Morris et al., 2006, p. 489 as cited in Diefenbach, 2011). For example, Bridgman (2007) notes a contradiction between the desire to financially capitalise on research (through commercialisation or engagement) and the increasing popularity of auditing the quality and quantity of an academic's research output.

It has been noted that engagement with industry may positively influence research publication. Perkmann et al. (2013), conclude that a faculty with strong industry connections publishes as many articles as faculties without these connections. Further, collaboration with industry may yield new insights and ideas for research. Whilst this is encouraging, unless organisational reward systems recognise this type of contribution it may be seen as less valuable than a traditional academic approach to research.

\footnotetext{
${ }^{2}$ KPI - Key Performance Indicators
} 
As noted earlier, extrinsically rewarding people for complex tasks that they find intrinsically motivating can 'crowd out' their willingness to perform such work. Yet, faculties continue to monitor, measure and reward academics on quantifiable research outputs and teaching time with little emphasis, if any, placed on the extent of their social capital and efforts to build and extend it.

In the authors' experience, Sadler's (2000) 'red tape' style constraints undermine the ability to pursue potential opportunities. The bureaucracy shows a lack of flexibility and speed in contexts where 'funding is not dependable, client demographics and needs are in flux, technology is rapidly changing, social and environmental pressures are increasing, skilled labour shortages are the norm, [and] citizens are calling for privatization' (Morris \& Jones 1999, p. 79). They point out that the greater the level of bureaucratisation, the greater the potential conflict with entrepreneurial behaviour.

Within entrepreneurship research, there is 'general consensus' that high levels of social capital are a particularly important asset for entrepreneurs; as their reputation, experience and personal relationships will lead to improved access to funding, information and customers (Liao \& Welsch, 2003, p. 151). Relational social capital in particular has a positive effect on entrepreneurial growth aspiration in organisations, by increasing an entrepreneur's ability to access and appropriate external resources (Liao \& Welsch, 2003).

Business schools are well placed to support academics who build on their industry experience. Reward systems will need to reflect such entrepreneurial approaches if universities are seeking long term productive relationships with industry.

\section{Conclusion and policy implications}

Exploring academic-industry engagement will be of interest to individual researchers and universities, especially business schools that increasingly draw on industry for their academic staff and their research funding. The ten practices offer a framework to help those new to academe and those wishing to develop or deepen their relationship with industry.

Despite the usefulness of this framework we remain troubled by the dissonance between being seen as successful, at one level at least, and the lack of organisational support and reward structures that are offered. For universities to foster more than the rhetoric of encouragement for entrepreneurial activities, five suggestions emerge.

Firstly, our analysis suggests that universities need to investigate reward systems that at times 'crowd out' individuals' intrinsic motivations to invest in their work. Academic work, particularly research, is complex and often long-term by nature and there can be long lead times before publication in highly ranked journals. Trying to annually quantify academics' performance on research outputs and the 'size of the prize' research grants can be at best an invalid assessment of their overall performance and at worst undermining and demotivating. The rhetoric in many business schools suggests that academic entrepreneurship is valued. However, crowding out will continue to work against such approaches. 
Secondly, if universities continue to pursue reward systems that rely on forms of quantification then they should investigate broader terms of reference that include practises leading to large industry based research grants. This will be particularly applicable for early-career researchers who, for example, could be assessed regarding frequency of contacts with relevant industry, that is, building structural social capital.

Thirdly, universities are often less responsiveness and at times have out-dated, inflexible protocols when engaging with industry. We appreciate that large private organisations and government clients have strident contractual and risk-management protocols that can slow the entire process. However, this is indeed a case of two wrongs not making a right. If business schools are to require their staff to engage in research or executive education with industry then they will need to be more responsive, less riskadverse and simply more pragmatic about how best to engage with industry.

Fourthly, if the expectation of university-industry engagement is to increase then universities need to provide adequate support for staff engagement and staff need to take advantage of the support offered. While large multi-disciplinary Centres of Excellence and winning competitive grants may be the domain of universities other opportunities exist, particularly at a school level, for smaller grants and executive education programs. Support could be aimed at appropriate development (for example, training, coaching, shadowing or mentoring) to build social capital. In addition, staff could be assessed on their strengths against the ten principles in the STRESS FREE framework and development offered where gaps exist.

Finally, it is vital to acknowledge that not only are universities unique in terms of their research output but so to are their schools; and individuals within these schools We have deliberately targeted our principles to staff within schools that are less likely to attract large scale competitive funding understanding that some staff members are exemplars in this area.

We assert that bridging the gap requires a review of what is measured and rewarded within business schools along with support for staff who understand clearly articulated expectations. The approach we have outlined provides a useful framework that can help bridge the gap between managerial demands and entrepreneurial approaches. 


\section{References}

ABC News. (2013). Educators, MPs furious over university funding cuts. http://www.abc.net.au/news/2013-04-14/educators-mps-furious-over-universityfunding-cuts/4627652.

Abreu, M., \& Grinevic, V. (2013). The nature of academic entrepreneurship in the UK: Widening the focus on entrepreneurial activities. Research Policy, 42, 408- 422.

Adler, P. S., \& Kwon, S. W. (2002). Social capital: Prospects for a new concept. Academy of management review, 27(1), 17-40.

Anderson, G. (2006). Carving out time and space in the managerial university. Journal of Organizational Change Management, 19 (5), 578-592.

Argyris, C. (1976). Single-loop and double loop models in research on decision making. Administrative Science Quarterly, 21 (3), 363-375.

Association to Advance Collegiate Schools of Business. 2012. Impact of Research a Guide for Business Schools Insights from the Aacsb International Impact of Research Exploratory Study.

http://www.aacsb.edu/ /media/AACSB/Publications/research-reports/impact-ofresearch-exploratory-study.ashx. Accessed 19 March 2015

Authors 2012 - To be completed after review of paper

Authors 2013 - To be completed after review of paper

Bercovitz, J., \& Feldman, M. (2008) Academic Entrepreneur: Organizational Change at the Individual Level. Organizational Science, 19(1), 69-89.

Bexley, E., (2014). Fee deregulation: what does it mean for Australian higher education? The Conversation. http://theconversation.com/fee-deregulation-whatdoes-it-mean-for-australian-higher-education-26496

Blatt, R. (2009). Tough Love: How Communal Schemas and Contracting Practices Build Relational Capital in Entrepreneurial Teams. Academy of Management Review. Vol. 34(3). 533-551.

Bilimoria, D., Godwin, L., and Zelechowski, D. (2007). Influence and inclusion; a framework for researching women's advancement in organizations. Handbook on Women in Business and Management. Bilimoria, D. and Piderit, S.K. (eds), Cheltenham, UK. Edward Elgar. 232-253. 
Blackmore, P., \& Kandiko, C.B. (2012). Academic Motivation: Exploring Prestige Economies, In Practice, 28, 1-4.

Bridgman, T. (2007). Freedom and autonomy in the university enterprise. Journal of Organizational Change Management, 20 (4), 478-490.

Carr, K. (2011). Creating links between researchers and industry. edited by Innovation Department of Industry, Science, Research and Tertiary Education: Australian Government.

Christopher, J. (2012). Tension between the corporate and collegial cultures of Australian public universities: the current status. Critical Perspectives on Accounting, 23 (7-8), 556-571.

Clark, B. R. 1998. Creating entrepreneurial universities: organizational pathways of transformation. Oxford; New York: Published for the IAU Press [by] Pergamon Press.

Coates, H., Dobson, I., Goedegebuure, L., \& Meek, L. (2010). Across the great divide: what do Australian academics think of university leadership? Advice from the CAP survey. Journal of Higher Education Policy and Management, 32 (4), 379-387.

Diefenbach, F. (2011). Entrepreneurship in the Public Sector. Wiesbaden: Springer Fachmedien.

De Carolis, D., \& Saparito, P. (2006). Social capital, cognition, and entrepreneurial opportunities: a theoretical framework. Entrepreneurship Theory and Practice, 30 (1), 41-56.

Dearlove, J. (2002). A continuing role for academics the governance of UK universities in the post-Dearing era. Higher Education Quarterly, 56 (3), 257-275.

Deem, R. (1998). New managerialism and higher education: the management of performances and cultures in universities in the United Kingdom. International Studies in Sociology of Education, 8 (1), 47-70.

Deem, R. (2001). Globalisation, new managerialism, academic capitalism and entrepreneurialism in universities: is the local dimension still important? Comparative Education, 37 (1), 7-20.

D'Este, P., \& Patel, P. (2007). University-industry linkages in the UK: What are the facvotr underlying the variety of interactions with industry? Research Policy 36 (2007), $1295-1313$. 
D'Este, P., \& Perkmann, M (2011). Why do academics engage with industry? The entrepreneurial university and individual motivations. The Journal of Knowledge Transfer 36, 316-339.

Edmondson, G., Valigra, L., Kenward, M., Hudson, R., \& Belfield, H (2012). Making Industry-University Partnerships Work: Lesson from successful collaborations. Science Business Innovation Board AISBL.

Fredman, N., \& Doughney, J. (2012). Academic dissatisfaction, managerial change and neo-liberalism. Higher education, 64 (1), 41-58.

Frey, B. (1997). A constitution for knaves crowds out civic virtues. The Economic Journal, 107, 1043-1053.

Frey, B., Hattke, F., \& Osterloh, M. (June 2013) Organizational control systems in the public sector and in research governance. Paper presented at the 13th Annual Conference of the European Academy of Management, Istanbul, Turkey.

Goxe, F., \& Viala, C. (2010). Social capital as a catalyst: enabling effect on organisational levers for corporate entrepreneurship. Paper presented at the ICSB World Conference, Cincinnati, $\mathrm{OH}$.

Harman, K., \& Treadgold, E. (2007). Changing patterns of governance for Australian universities. Higher Education \& Research Development, 26 (1), 13-29.

Hewitt-Dundas, N. (2012). Research intensity and knowledge transfer activity in UK unversities. Research Policy, 41 (2), 262-275.

Hil, R. (2012). Whackademia: An insider's account of the troubled university. Sydney: New South Publishing.

Hood, C. (1995). The 'new public management' in the 1980s: variations on a theme'. Accounting, Organizations and Society, 20 (2-3), 93-109.

Ireland, R.D., Kuratko, D.F., \& Morris, M.H. (2006). A health audit for corporate entrepreneurship: innovation at all levels: part 1. Journal of Business Strategy, 27 (1), 623-632.

Kenny, J.D. (2009). Managing a modern university: is it time for a rethink?. Higher Education Research \& Development, 28 (6), 629-642. 
Lawson, B., Tyler, B., \& Cousins, P. (2006). Social capital effects on relational performance improvement: an information processing perspective. Paper presented at Academy of Management Meeting, Atlanta, GA.

Lee, R. (2008). Social Capital and Business and Management: Setting a Research Agenda. International Journal of Management Reviews, 11 (3), 247-273.

Liao, J.. \& Welsch, H. (2003). Social capital and entrepreneurial growth aspiration: a comparison of technology and non-technology based nascent entrepreneurs. Journal of High Technology Management Research, 14, 149-170.

Luthans, K., \& Leung, A. (2010). Development of human and social capital through industry peer networks. Paper presented at Business Research Yearbook: Global Business Perspectives.

Mintzberg, H. (1979). The structuring of organizations: A synthesis of the research. Englewoods Cliffs, NJ: Prentice Hall.

Moran, P. (2005). Structural versus relational embeddedness: social capital and managerial performance. Strategic Management Journal, 26, 1129-1151.

Morris, M., \& Jones, F. (1999). Entrepreneurship in established organizations: the case of the public sector. Entrepreneurship Theory and Practice, 24 (1), 71-91

Musselin, C. (2013). Redefinition of the relationships between academics and their university. Higher Education, 65, 25-37

Nahapiet, J., \& Ghosal, S. (1998). Social capital, intellectual capital and the organizational advantage. Academy of Management Review, 23 (2), 242-266.

Osterloh, M., Frey, B., \& Frost, J. (2001). Managing motivation, organization and governance. Journal of Management and Governance, 5 (3-4), 231-239.

Perkmann, M., Tartari, V., McKelvey, M., Autio, E., Broström, A., D’Ested, P., Riccardo, F., Geunael, A., Grimaldif, R., Hughes, A., Krabel, S., Kitson, M., Llerena, P., Lissoni, F., Salter, A. \& Sobrero, M. (2013). Academic engagement and commercialisation: a review of the literature on university-industry relations. Research Policy, 42, 423-442.

Pick, D., Teo, S., \& Yeung, M. (2012). Friend or foe? New managerialism and technical, administrative and clerical support staff in Australian universities. Higher Education Quarterly, 66 (1), 3-23. 
Ramsden, P. (1998). Managing the effective university. Higher Education Research \& Development, 17 (3), 347-370.

Sadler, R. (2000). Corporate entrepreneurship in the public sector: the dance of the chameleon. Australian Journal of Public Administration, 59 (2), 25-43.

Saunders, M. (2006). The Madness and Malady of Managerialism. Quadrant, 50(3), 917.

Schön, D. (1983). The Reflective Practitioner. New York. Basic Books.

Shane, S., \& Venkataraman, S. (1996). Renegade and rational championing strategies. Organization Studies, 17 (5), 751-771.

Shane, S. (2003). A general theory of entrepreneurship: the individual-opportunity nexus. Cheltenham UK: Edward Elgar.

Sharrock, G. (2007). After Copernicus: beyond the crisis in Australian universities. Australian Universities Review, 49 (1-2), 2-14.

Sharrock, G. (2012). Four management agendas for Australian universities. Journal of Higher Education Policy and Management, 34 (3), 323-337.

Szekeres, J. (2007). General staff experiences in the corporate university. Journal of Higher Education Policy and Management, 28 (2), 133-145.

Tsai, W., \& Ghosal, S. (1998). Social capital and value creation: the role of intrafirm networks. Academy of Management Journal, 41 (4), 464-476.

Triechmann, J.S., Dennis, A.R., Northcraft, G.B., and NiemeJr, A.W. (2000). Serving Constituencies in Business Schools: MBA Program Versus Research Performance. Academy of Management Journal, 43(6), 1130-1141.

Voronov, M., Wolfram-Cox, J., Le Trent-Jones, T., \& Weir, D. (2009). Introduction: intersection of critical management research and practice: a multi-domain perspective. In M.Voronov, J. Wolfram Cox, T. Le Trent-Jones and D. Weir (eds.), Critical management studies at work: negotiating the tensions between theory and practice (116). Cheltenham: Edward Elgar.

Weibel, A., Rost, K., and Osterloh, M. (2009). Pay for performance in the public sector - benefits and (hidden) costs. Journal of Public Administration Research and Theory, $20,387-412$. 
Washington, M.L. (2008). It's whom you know and what you know: a social capital perspective of the effect of small firm organisational learning on firm performance. (UMI No. 3326390).

White, K., Carvalho, T., \& Riordan, S. (2011). Gender, power and managerialism in universities. Journal of Higher Education Policy and Management, 33 (2), 179-188.

Wilken, P. H. (1979). Entrepreneurship: a comparative and historical study. Norwood: Ablex.

Wright, M., Simon Mosey, S. \& Noke, H. (2012). Academic entrepreneurship and economic competitiveness: rethinking the role of the entrepreneur. Economics of Innovation and New Technology, 21 (5-6), 429-444.

Zahra, S. A. (2010). Harvesting family firms organizational social capital: a relational perspective. Journal of Management Studies, 42 (2), 345-366.

Zimmerman, J.L. (2001). Can American Business Schools Survive? Social Science Research Network. Available at SSRN: http://ssrn.com/abstract $=283112$ or http://dx.doi.org/10.2139/ssrn.283112 